\title{
POTENTIAL OF GLASS CULLET AS AGGREGATE IN HOT MIX ASPHALT
}

\author{
H. M. Alhassan ${ }^{1}{ }^{*}$, G. H. Yunusa ${ }^{2}$ and D. Sanusi ${ }^{3}$ \\ 1, 2,3, DePARTMENT OF Civil ENGINEERING, BAYERo University, KANo, KANo STATE. NIGERIA \\ E-mail addresses:1hmalhassan.civ@buk.edu.ng,2ghyunusa.civ@buk.edu.ng,3dsanusi146@gmail.com
}

\begin{abstract}
The increasing quantity of non-biodegradable waste has posed major environmental concern especially in the developing countries. To improve such challenge, the effects of crushed waste glass bottles (cullet) as partial replacement of fine aggregate in the properties of Hot Mix Asphalt (HMA) was investigated. The waste glass was crushed and sieved through series of sieves to determine its gradation. The optimum bitumen content (OBC) was determined using Marshall Mix Design Method. A total of 33 cylindrical specimen of asphalt produced with sand and sand partially replaced with glass cullet were prepared. 15 specimen were used to determine the $O B C$ using of 5.0, 5.5, $6.0,6.5$ and $7.0 \%$ bitumen to the total blended aggregate weight. The remaining samples were used to investigate the effects of glass cullet on the bituminous mixture at the selected $O B C$ using Marshall Test. The results of the laboratory tests indicate $O B C$ of 5.9\%. Stability, flow, specific gravity and air voids were determined from the Marshall test and were compared with those specified by The Asphalt Institute and the Nigerian codes for Roads and Bridges. Optimum glass cullet content of $8.0 \%$ was obtained. Asphalt produced with $8 \%$ glass cullet can be used as wearing course material. Use of glass cullet will provide an effective way of disposing the waste.
\end{abstract}

Keywords: Glass cullet, Glasphalt, Hot mix asphalt, Optimum bitumen content, wearing course, Marshall test, Aggregate.

\section{INTRODUCTION}

Waste is any material that is a by-product of human and industrial activities with no lasting value [1]. Numerous waste materials results from manufacturing operations, service industries, mining, sewage treatment plants, households etc. The increase in generated waste quantities and types of waste materials, the shortage of landfill spaces, and the over use of natural earth materials highlight the urgency of finding innovative ways of recycling and reusing waste material [2]. Previous studies such as Murana and Sani [3] and Otuoze and Shuaibu[4] have demonstrated the possibility of partially replacing cement with bagasse ash in hot mix asphalt and the use of polypropylene waste in bituminous mix. Glass being non-metallic and inorganic waste material, can neither be cremated nor decomposed by microbes. Therefore, glass waste require careful handling to avoid injuries and also require special disposal methods. For this reason, underground burial has been widely practised especially in developing countries as one of the possible solution. According to Tobore, [5], the proportion of glass waste in the domestically generated refuse in Kano state is estimated to be around $8.7 \%$ of the total solid waste of about 156,676 tons per month.

Glass is a product of the super cooling of a melted liquid mixture consisting primarily of sand (silicon dioxide) and soda ash (sodium carbonate) to a rigid condition, in which the super cooled material does not crystallize and retains the organization and internal structure of the melted liquid [6]. Although glass is often recycled by the glass manufacturing industries, it however must be sorted by colour because mixed coloured glass is generally unsuitable for traditional recycling processes due to small sizes and the requirement to separate glass colours for reprocessing [7]. Interestingly, when waste glass is crushed to sandlike particle sizes, similar to those of natural sand, it exhibits properties of an aggregate material [6]. It similarly possess most of the properties of high quality natural silica sand and is free of clay and other contaminants. Being almost totally inert, with low absorption, extremely durable and hence provides a greater effective binder content in the mixing of asphalt [7]. 
Some countries utilize waste glass in highway construction as an aggregate substitute in hot mix asphalt paving. In fact countries like Japan, United States and several European nations have recently incorporated glass into their roadway specifications, which had encouraged greater use of the material [8; 9]. When crushed waste glass is incorporated in HMA the resulting mixture is sometimes referred to as "Glasphalt" [10].

Some researches reported the utilization of waste glass material as highway construction material, Viswanathan [11] studied the characterization of waste recycled glass as highway material, and found that glass cullet has properties similar to natural aggregates and could be used as highway construction material. $\mathrm{Wu}$ et al. [12] studied the performance of asphalt concrete where some of the fractional fine aggregate was substituted with crushed glass material. The research demonstrated that the use of waste glass in asphalt concrete is feasible and could be used in asphalt concrete with a maximal size of $4.75 \mathrm{~mm}$. To conform to the standards, the optimal replacement ratio is $10 \%$ and this could maintain the performances such as strength index, high temperature stability and water stability [6]. Crushed recycled glass, can be used as a supplement to natural road base material but limited to maximum replacement rate and size of $20 \%$ and $12.5 \mathrm{~mm}$. It is more feasible to use glass cullet with crushed, angular aggregate since it performs more consistently than when blended with rounded natural aggregate [13]. Moreover, the used of glass powder filler mixtures compared to Portland cement or Limestone powder fillers in HMA was investigated [14], but not much work has been done on the effect of waste glass as aggregate in hot mix asphalt. Hence, this study was aimed at the evaluation of the effect of waste glass cullet as aggregate on the properties of hot mix asphalt.

\section{MATERIAL AND METHODS}

\subsection{Material}

Material used in this study include the natural aggregates, Bitumen of $60 / 70$ and waste glass cullet. Bitumen of $60 / 70$ penetration grade was obtained from Setraco Nigeria limited. The waste glass bottle was obtained from Nigerian Brewery wastes bottles Stockpile, Kaduna Expressway. While the natural aggregates used in this study are those that satisfied the specification for hot mix asphalt as recommended by ASTM and BS standards.

The crushed waste glass was obtained from waste bottles and blended with the aggregates. The waste bottles were hand-picked, cleaned before manually being crushed to fine sizes (cullet) of the required gradation. Plates 1 and 2, shows different particle sizes of the waste glass and waste glass and fine aggregate, respectively used in this study.

\subsection{Methods}

The methodology adopted in this study begins by evaluating the properties of the materials used in the study (i.e. bitumen, aggregates, and crushed waste glass). Sieve analysis was performed on the aggregates and crushed waste glass. Consistency tests on the bituminous cement were also conducted.

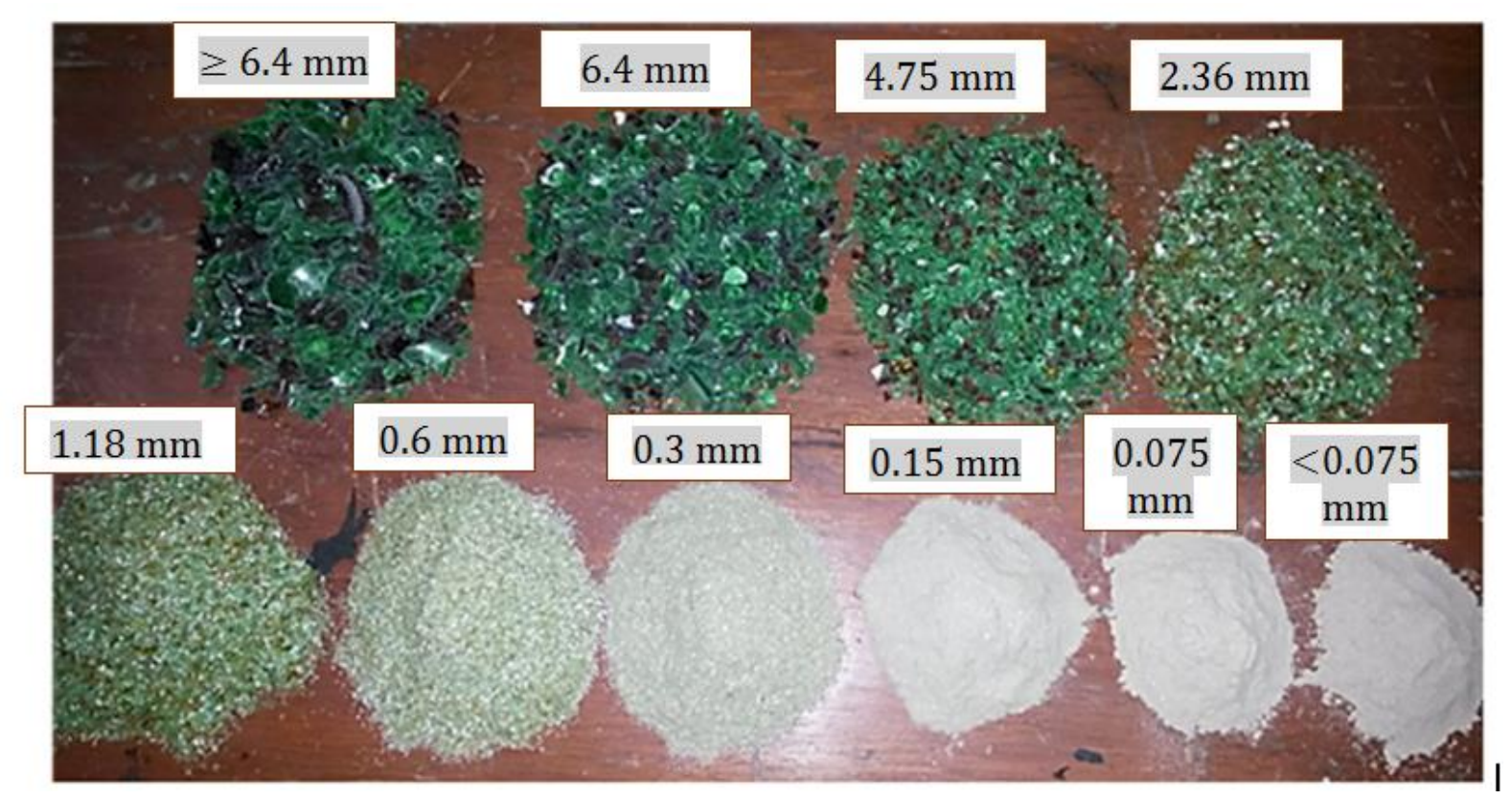

Plate 1: Crushed Waste Glass retained on specified sieve size for wearing course gradation 


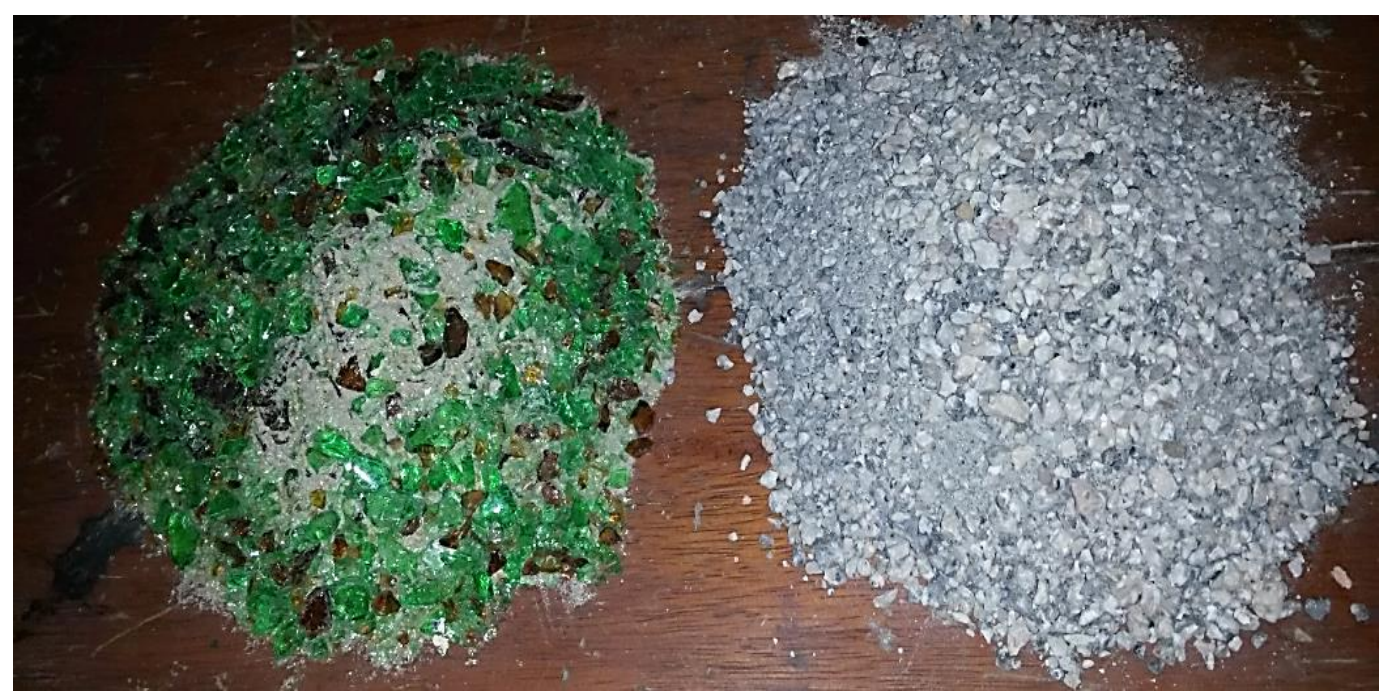

Plate 2: Crushed Waste glass and Fine aggregates used in the mixture

For the crushed waste glass and each aggregate type, blending of aggregate was carried out to obtain the wearing course gradation curve used in the preparation of the hot mix asphalt based on Marshall Method of mix design [16]. Different asphalt specimens were prepared with 5 to $7 \%$ to obtain optimum bitumen content by Marshall Test. The optimum bitumen content obtained was used to prepare asphalt mix samples with variation 5, 6, 7, 8, 9 and $10 \%$ glass cullet by weight of sand. Marshall Test (density-voids analysis and a stability-flow test) were used to evaluate the properties of these mixes.

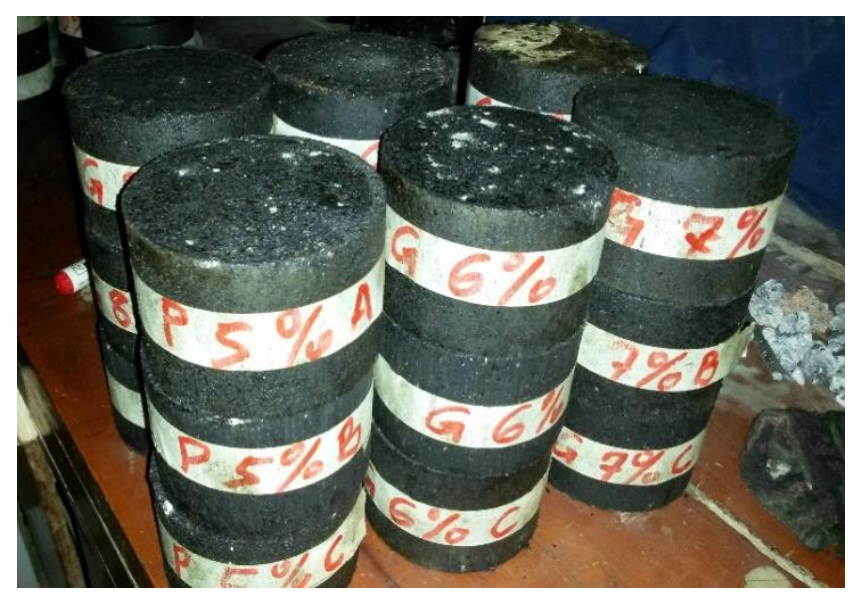

Plate 3: Prepared HMA sample

2.2.1 Preparation of Mixtures: According to ASTM specifications using mathematical trial method, aggregates were blended together in order to obtain a proper gradation. Each aggregate sample was blended separately for each specimen, before being oven dried to constant weight at $110 \pm 5^{\circ} \mathrm{C}$. The aggregate was then heated to a temperature of $170^{\circ} \mathrm{C}$ before mixing with asphalt cement. Asphalt was heated up to $145^{\circ} \mathrm{C}$ prior to mixing, the required amount of asphalt was then

Nigerian Journal of Technology, added to the heated aggregate and mixed thoroughly for at least three minutes until a homogenous mix was obtained. Standard Marshall moulds were heated in an oven to $130^{\circ} \mathrm{C}$. The hot mixture was placed in the mould and each face was compacted with 50 blows. The specimens were allowed to cool in air at room temperature until it can be demoulded without deformation. Plate 3 shows prepared HMA samples.

\subsubsection{Marshall Method}

The two principal features of the Marshall method of mix design are, a density-voids analysis and a stabilityflow test of the compacted test specimens. The method covers the measurement of the resistance to plastic flow of cylindrical shaped specimens of bituminous paving mixture loaded on the lateral surface by means of the Marshall apparatus according to ASTM D 155989. Marshall Stability and flow tests were performed on each specimen after it was cooled at room temperature for 24 hours. The cylindrical specimen was placed in a water bath at $60{ }^{\circ} \mathrm{C}$ for 30 to 40 minutes then compressed on the lateral surface at constant rate of $50.8 \mathrm{~mm} / \mathrm{min}$ until the maximum load (failure) is reached. The maximum load resistance and the corresponding flow value were then recorded. Three specimens for each combination were prepared and the average results were reported. The bulk specific gravity, density, air voids in total mix, and voids filled with bitumen percentages were determined for each specimen. The stability of the specimen is the maximum load required to produce failure of the specimen when load is applied at constant rate of 50 $\mathrm{mm} / \mathrm{min}$ [17]. It is expected that as the Bitumen content increase so should the Stability. Hence flow value is the total movement or displacement, in unit of $0.25 \mathrm{~mm}$, occurring in specimen between no load and 
the point of maximum load during the stability test [18].

\subsubsection{Optimum Crushed waste glass content}

A number of laboratory investigations were performed in order to determine the mix properties of the modified asphalt with glass cullet using Marshall Method of mix design procedure. All mixtures were prepared with the same optimum bitumen content (5.9\%). The appropriate percentage of crushed waste glass cullet used in this study was determined from six different prepared specimen with crushed waste glass content of $5.0,6.0,7.0,8.0,9.0$, and $10.0 \%$ by weight of the total aggregate and 3 samples per each percentage were investigated.

\section{RESULTS AND DISCUSSIONS}

The physical properties of the aggregate used in this study and its gradation curve obtained from sieve analysis are shown in Table 1 and Figure 1, respectively. The crushed glass possessed a density of $2.52 \mathrm{~g} / \mathrm{cm}^{3}$ and its gradation was completely uniform with the maximum particle size of $4.75 \mathrm{~mm}$.

Table 1 shows that the aggregate satisfied the recommended specification by ASTM and BS. The sieve analysis results in Figure 4 shows that the gradation curve is in between the maximum and minimum recommended values specified by ASTM, hence it's suitable to be used in the preparation of HMA. Figure 2 shows the grain size distribution of both the fine aggregate and crushed waste glass used in the asphalt mixture.

The physical properties of the bitumen of $60 / 70$ penetration grade used in this study are presented in Table 2, which shows that the bitumen satisfied the recommended specification stipulated in ASTM.

\subsection{Marshall Test for Asphaltic mixture}

The results obtained from Marshall Test for asphaltic mixture are summarized in Table 3.

Table 1: Physical and Mechanical properties of aggregates used

\begin{tabular}{|c|c|c|c|c|c|}
\hline Test & $\begin{array}{c}\text { ASTM/BS } \\
\text { Designation }\end{array}$ & $\begin{array}{c}12.5-6.40 \\
\mathrm{~mm}\end{array}$ & $\begin{array}{c}4.75-0.60 \\
\mathrm{~mm}\end{array}$ & $\begin{array}{c}0.425-0.075 \\
\mu \mathrm{m}\end{array}$ & $\begin{array}{c}\text { Specification } \\
\text { limits } \\
\end{array}$ \\
\hline Bulk dry S.G & \multirow{3}{*}{$\mathrm{C} 127$} & 2.80 & 2.78 & & \multirow{3}{*}{-} \\
\hline Bulk SSD S.G & & 2.83 & 2.81 & & \\
\hline Apparent S.G & & 2.67 & 2.63 & & \\
\hline Absorption (\%) & $\mathrm{C} 128$ & 0.8 & 0.7 & 0.5 & $<5$ \\
\hline Abrasion value (\%) & $\mathrm{C} 131$ & 14 & - & - & $<40$ \\
\hline Crushing value (\%) & \multirow{2}{*}{$\begin{array}{c}\text { BS812: Part 110, } \\
1990\end{array}$} & 20 & - & - & $<30$ \\
\hline Impact value (\%) & & 24 & - & - & $<30$ \\
\hline Flakiness index (\%) & \multirow{2}{*}{$\begin{array}{c}\text { BS812: Part 105, } \\
1989\end{array}$} & 11 & - & - & $<25$ \\
\hline Elongation index (\%) & & 19 & - & - & $<25$ \\
\hline
\end{tabular}

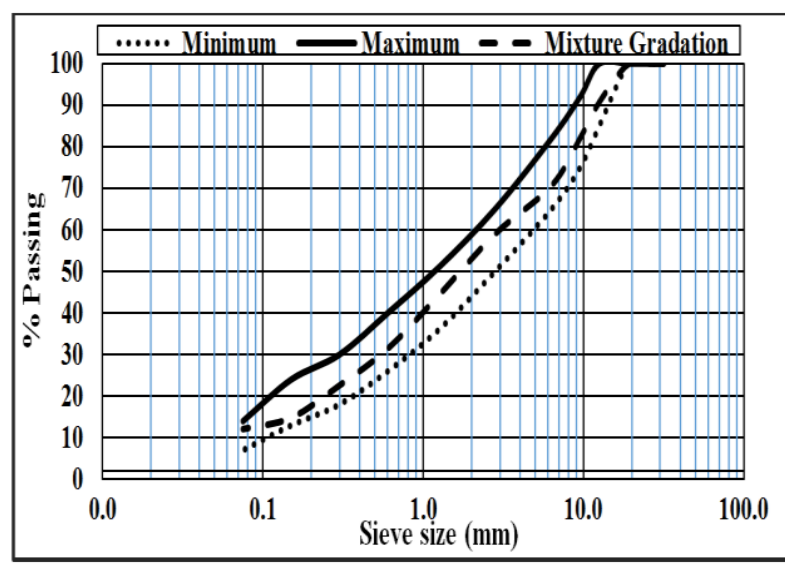

Figure 1: ASTM D 3515 Gradation curves limits and aggregates mixture gradation curve

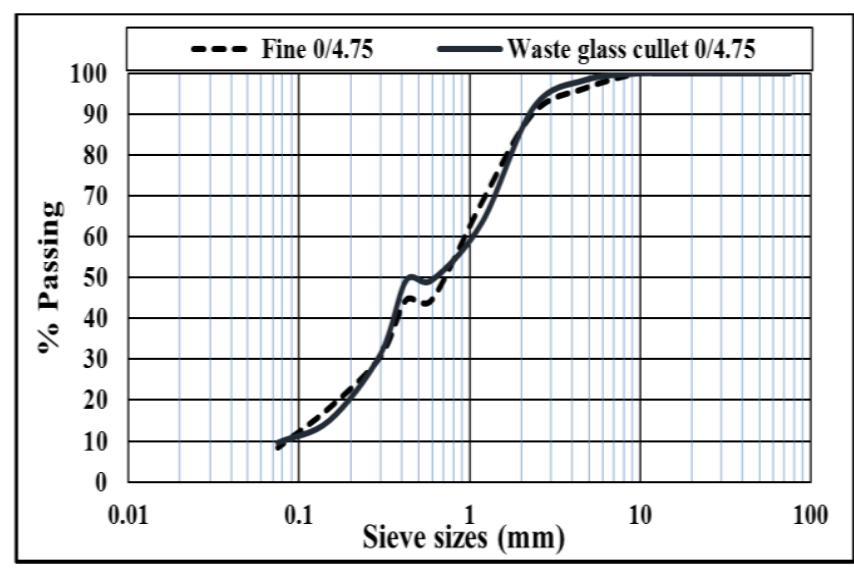

Figure 2: Gradation curve of used Crushed Waste Glass and Fine aggregate 
Table 2: Physical properties of bitumen

\begin{tabular}{lcccc}
\hline Test & Unit & Reference code & Test result & Range specified by code \\
\hline Penetration at $25^{\circ} \mathrm{C}$ & $1 / 10 \mathrm{~mm}$ & ASTM D5-06 & 60.2 & $60-70$ \\
Specific Gravity at $25^{\circ} \mathrm{C}$ & $\mathrm{g} / \mathrm{cm}^{3}$ & ASTM D70 & 1.02 & $1.01-1.06$ \\
Softening Point & ${ }^{\circ} \mathrm{C}$ & ASTM D36-2002 & 47 & $(45-52)$ \\
Flash Point & ${ }^{\circ} \mathrm{C}$ & ASTM D92-90 & 274 & Min $230{ }^{\circ} \mathrm{C}$ \\
\hline
\end{tabular}

Table 3: Summary of results obtained by Marshall Test for Asphaltic mixture

\begin{tabular}{cccccccccc}
\hline $\begin{array}{c}\text { Bitumen } \\
\text { content } \\
\text { by weight } \\
(\%)\end{array}$ & $\begin{array}{c}\text { Effective } \\
\text { Bitumen } \\
\text { content. } \\
(\%)\end{array}$ & $\begin{array}{c}\text { Sample } \\
\text { No. }\end{array}$ & $\begin{array}{c}\rho_{A} \\
\left(\mathrm{~g} / \mathrm{cm}^{3}\right)\end{array}$ & $\begin{array}{c}V_{a} \\
(\%)\end{array}$ & $\begin{array}{l}V_{b}(\%) \\
\text { VMA } \\
(\%)\end{array}$ & $\begin{array}{c}V F B \\
(\%)\end{array}$ & $\begin{array}{c}\text { Corrected } \\
\text { Stability } \\
(\mathrm{kN})\end{array}$ & $\begin{array}{c}\text { Flow } \\
(\mathrm{mm})\end{array}$ \\
\hline 5.0 & 4.7 & 3 & 2.350 & 4.86 & 10.78 & 17.75 & 67.41 & 114.33 & 3.20 \\
5.5 & 5.2 & 3 & 2.344 & 4.75 & 11.90 & 17.31 & 71.53 & 16.15 & 2.95 \\
6.0 & 5.7 & 3 & 2.360 & 3.67 & 13.14 & 16.64 & 79.59 & 20.23 & 2.80 \\
6.5 & 6.2 & 3 & 2.351 & 2.89 & 14.23 & 16.51 & 82.25 & 19.59 & 3.17 \\
7.0 & 6.7 & 3 & 2.350 & 2.49 & 15.37 & 15.99 & 86.59 & 15.46 & 3.28 \\
\hline
\end{tabular}

Where $\rho_{A}$ - Bulk Density, $V_{a}$ - Air voids, $V_{b}$ - Percent volume of bitumen, VMA - Voids in Mineral Aggregates,

VFB - Percent Voids Filled with Bitumen.

\subsubsection{Marshall Stability and Flow}

The maximum stability of the asphalt mix is $19.6 \mathrm{kN}$ at $6.10 \%$ bitumen content. It was noticed that the highest and lowest flow of the asphalt mix was at $7 \%$ and $6 \%$ bitumen content, respectively.

\subsubsection{Bulk Density and Air Voids Content $\left(V_{a}\right)$}

Bulk density is the actual density of the compacted mix. It was noticed that the highest and lowest bulk density were $2.35 \mathrm{~g} / \mathrm{cm}^{3}$ and $2.34 \mathrm{~g} / \mathrm{cm}^{3}$ at $6.0 \%$ and $5.5 \%$ bitumen content respectively. The air voids, $V a$, is the total volume of the small pockets of air between the coated aggregate particles throughout a compacted paving mixture, expressed as a percent of the bulk volume of the compacted paving mixture [18]. It was noticed that the air voids content gradually decreases with increasing in the bitumen content which was due to more voids percentage filled with bitumen in the asphalt mix.

\subsubsection{Voids in Mineral Aggregates (VMA) and filled with Bitumen (VFB)}

Voids in the mineral aggregate (VMA) are the intergranular void space between the aggregate particles in a compacted paving mixture that includes the air voids and the effective bitumen content, expressed as a percent of the total volume [18]. This property gradually decreased as the bitumen content increased, this was due to lesser intergranular voids between the aggregate particles in a compacted paving mixture that includes both the air voids and the effective bitumen content. And voids filled with bitumen (VFB), is the percentage of the intergranular void space between the aggregate particles (VMA) that are filled with bitumen [18]. The VFB\% increased gradually as bitumen content in the asphalt mix increased, this was due to the fact that more effective bitumen content was present in the mix to filled available voids between the intergranular spaces.

\subsection{Optimum Bitumen Content (OBC)}

The determined optimum bitumen content (OBC) is presented in Table 4.

\section{Table 4: Optimum bitumen content (OBC)}

\begin{tabular}{ll}
\hline Bitumen content at the maximum stability & $6.10 \%$ \\
\hline $\begin{array}{l}\text { Bitumen content at the maximum value of } \\
\text { bulk density }\end{array}$ & $6.0 \%$ \\
\hline $\begin{array}{l}\text { Bitumen content at the median percent of } \\
\text { air voids }\end{array}$ & $5.7 \%$ \\
\hline Optimum Bitumen Content (OBC) & $5.9 \%$ \\
\hline
\end{tabular}

From Table 4, the optimum bitumen content was found to equal $5.9 \%$ by weight of the total mix which was calculated as the average of bitumen content values that correspond with the maximum stability, maximum density and median of the air voids. Figures plotted from Table 3 are used to find the three values, as follows:

$$
O B C=\frac{6.10+6.0+5.57}{3}=5.89 \approx 5.9 \%
$$

The properties of the asphalt mix at the optimum bitumen content is presented in Table 5. Similarly the summary of the Marshal Test result at 5.9\% bitumen content using different percentages of glass cullet is presented in Table 6. 
Table 5: Properties of the asphalt mix at 5.9\% bitumen content

\begin{tabular}{|c|c|c|c|c|c|}
\hline \multirow[t]{2}{*}{ Test } & \multirow[t]{2}{*}{ Test Result } & \multicolumn{2}{|c|}{$\begin{array}{l}\text { Asphalt Institute } 1997 \\
\text { range }\end{array}$} & \multicolumn{2}{|c|}{$\begin{array}{l}\text { F.M.W Nigeria, } 1997 \\
\text { range }\end{array}$} \\
\hline & & Min & $\operatorname{Max}$ & Min & $\operatorname{Max}$ \\
\hline Traffic type & Medium & $10^{4}$ & $10^{6}$ & * & * \\
\hline $\begin{array}{l}\text { Compaction (No. of blows to each } \\
\text { ends of specimen) }\end{array}$ & 50 & \multicolumn{2}{|c|}{50} & \multicolumn{2}{|c|}{50} \\
\hline Stability (kN) & 19.45 & 5.3 & $*$ & 3.5 & $*$ \\
\hline Flow (mm) & 3.1 & 2 & 4 & 2 & 4 \\
\hline Bulk density $\left(\mathrm{gm} / \mathrm{cm}^{3}\right)$ & 2.35 & 2.3 & $*$ & 2.3 & $*$ \\
\hline Air voids (\%) & 3.6 & 3 & 5 & 3 & 5 \\
\hline Voids filled with bitumen (\%) & 76 & 65 & 78 & 75 & 82 \\
\hline Voids in Mineral Aggregate (\%) & 16.9 & 13 & * & * & * \\
\hline
\end{tabular}

Table 6: Properties of asphalt mixes with different glass cullet content at optimum bitumen content

\begin{tabular}{ccccccccc}
\hline $\begin{array}{c}\text { Glass Cullet } \\
\text { Content }(\%)\end{array}$ & $\begin{array}{c}\text { Number of } \\
\text { Specimen } \\
\text { tested }\end{array}$ & $\begin{array}{c}\rho \mathrm{A} \\
\left(\mathrm{g} / \mathrm{cm}^{3}\right)\end{array}$ & $V_{a}(\%)$ & $\begin{array}{c}V_{b} \\
(\%)\end{array}$ & $\begin{array}{c}\text { VMA } \\
(\%)\end{array}$ & $\begin{array}{c}\text { VFB } \\
(\%)\end{array}$ & $\begin{array}{c}\text { Corrected } \\
\text { Stability } \\
(\mathrm{kN})\end{array}$ & $\begin{array}{c}\text { Flow } \\
(\mathrm{mm})\end{array}$ \\
\hline 0 & 3 & 2.35 & 3.60 & 13.30 & 16.90 & 76.00 & 19.45 & 3.10 \\
5.0 & 3 & 2.33 & 3.61 & 12.72 & 16.33 & 77.87 & 16.71 & 3.19 \\
6.0 & 3 & 2.34 & 3.17 & 12.78 & 15.94 & 80.15 & 16.59 & 3.20 \\
7.0 & 3 & 2.33 & 3.53 & 12.73 & 16.27 & 78.39 & 17.53 & 3.37 \\
8.0 & 3 & 2.32 & 3.91 & 12.68 & 16.60 & 76.42 & 17.79 & 3.37 \\
9.0 & 3 & 2.33 & 3.70 & 12.72 & 16.24 & 77.47 & 16.89 & 3.43 \\
10.0 & 3 & 2.31 & 4.36 & 12.63 & 16.99 & 74.7 & 17.67 & 3.47 \\
\hline
\end{tabular}

3.3 Effect of glass cullet on the properties of Hot Mix Asphalt

\subsubsection{Marshall Stability - Glass content relationship}

The effect of glass cullet on stability of hot mix asphalt is presented in Figure 3, the stability of Glasphalt mixes increased with glass cullet content to maximum value of $17.79 \mathrm{kN}$ at $8.0 \%$ glass content. The stability value of the mix for all content of glass surpass both the local and international specifications, thus making glass a candidate for selection in asphalt mix production.

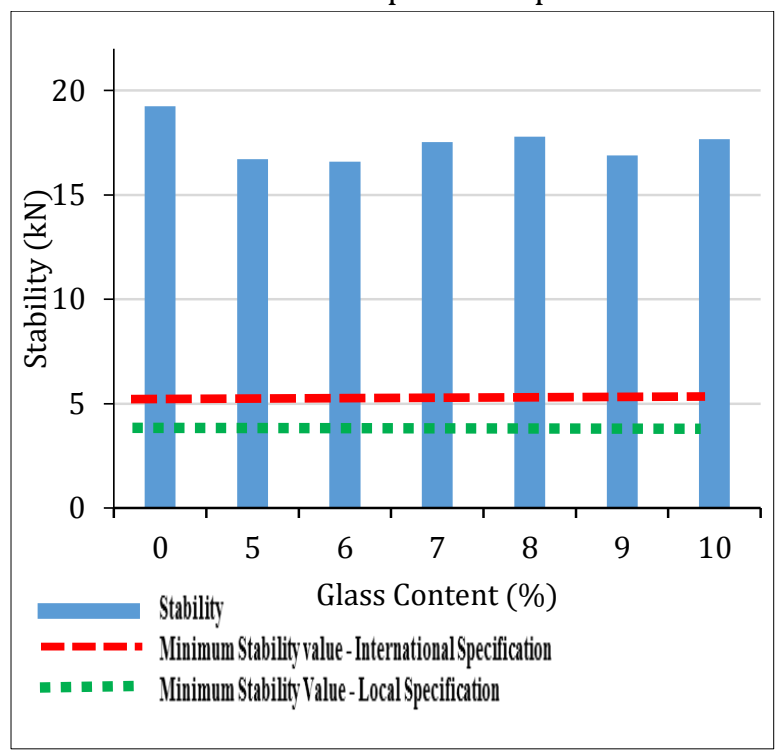

Figure 3: Asphalt mix stability - Glass content relationship

Nigerian Journal of Technology,

\subsubsection{Air voids $\left(V_{a}\right)$ - Glass content relationship}

Figure 4 shows the relationship between the air void for glasphalt and the glass content. The air voids of glasphalt increased gradually with glass cullet content increased. It was noticed that at $8.0 \%$ glass content the air voids percentage was 3.9 , which is the median value of Asphalt Institute and Nigerian code.

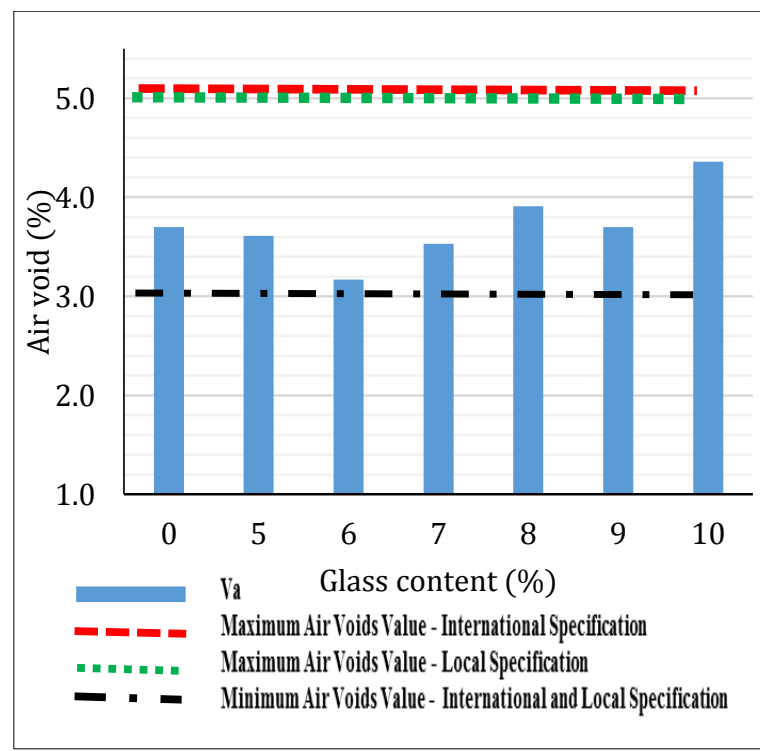

Figure 4: Asphalt mix air voids - Glass content relationship 


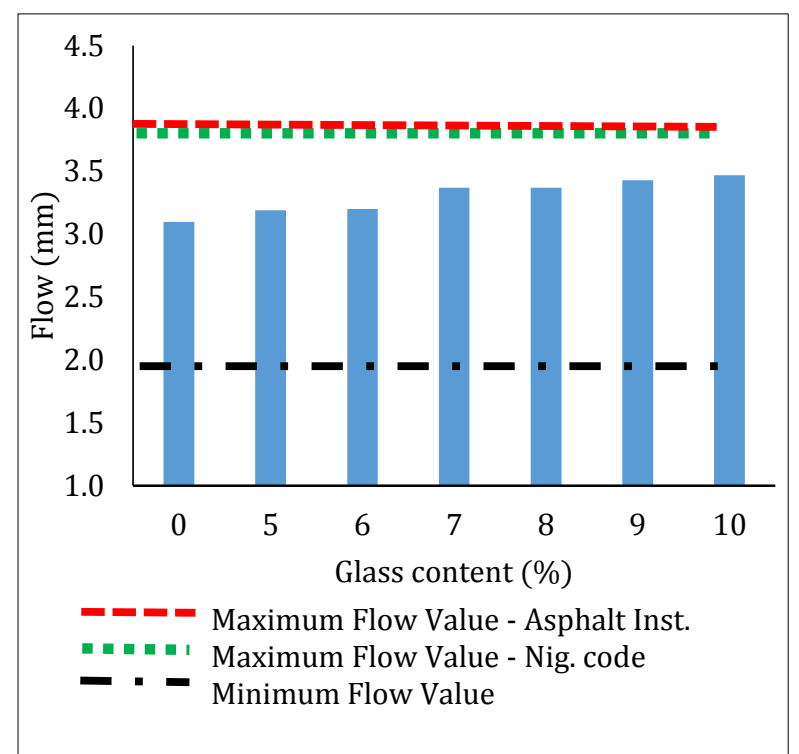

Figure 5: Asphalt mix flow - Glass content relationship

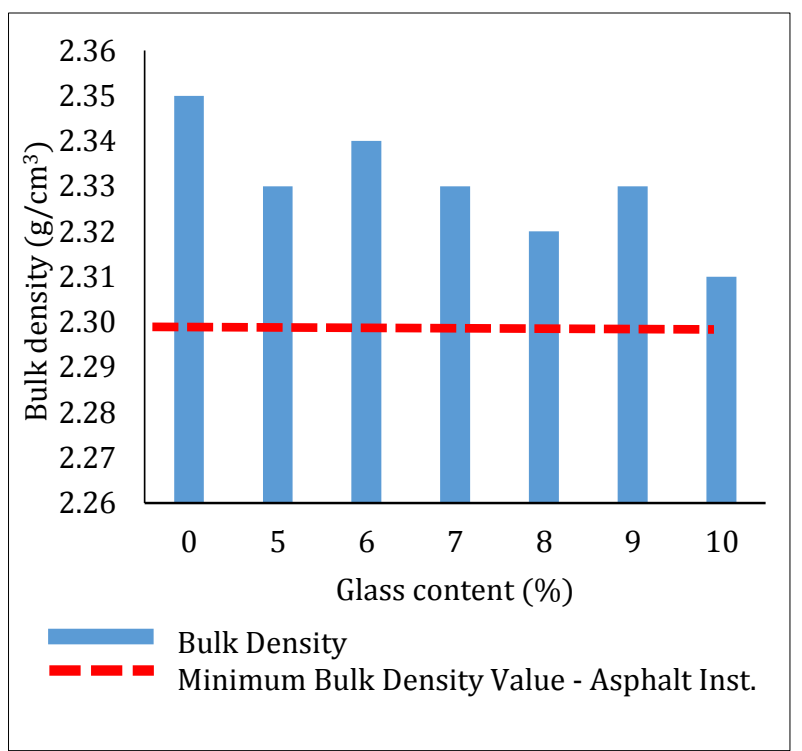

Figure 6: Asphalt mix bulk density - Glass content relationship

Table 7: Comparison of Glasphalt mix with optimum content and the Asphalt Institute and the Nigerian code specifications range

\begin{tabular}{|c|c|c|c|c|c|}
\hline \multirow[t]{2}{*}{ Properties } & \multirow{2}{*}{$\begin{array}{c}\text { Glass content } \\
8.0 \%\end{array}$} & \multicolumn{2}{|c|}{$\begin{array}{c}\text { Asphalt Institute } 1999 \\
\text { range }\end{array}$} & \multicolumn{2}{|c|}{$\begin{array}{c}\text { F.M.W. Nigeria } 1997 \\
\text { range }\end{array}$} \\
\hline & & Min & $\operatorname{Max}$ & Min & $\operatorname{Max}$ \\
\hline Stability $(\mathrm{kN})$ & 17.79 & 5.3 & $*$ & 3.5 & $*$ \\
\hline Flow (mm) & 3.4 & 2 & 4 & 2 & 4 \\
\hline Bulk density $\left(\mathrm{g} / \mathrm{cm}^{3}\right)$ & 2.32 & 2.3 & $*$ & 2.3 & $*$ \\
\hline Voids in Total Mix $\left(V_{a}\right)$ & 3.9 & 3 & 5 & 3 & 5 \\
\hline Voids filled with bitumen (VFB) & 75.4 & 65 & 78 & 75 & 82 \\
\hline $\begin{array}{l}\text { Voids in Mineral Aggregate } \\
\text { (VMA) }\end{array}$ & 16.8 & 13 & $*$ & $*$ & * \\
\hline
\end{tabular}

\subsubsection{Flow - Glass content relationship}

Figure 5 shows relationship between the flow value of glasphalt and the glass cullet content. The flow value of glasphalt mixes oscillate around the value of conventional mixed asphalt (HMA) which is $3.1 \mathrm{~mm}$, the glasphalt flow values are all within the international and local specifications range at different glass content.

\subsubsection{Bulk density - Glass content relationship}

Figure 6 gives the relationship between the bulk density for glasphalt and the glass content. The bulk density of glasphalt mixes with the different percentages of glass cullet content are within values specified by the Asphalt Institute and the Nigerian code. The general trend shows that the bulk density varies as the glass content increases. Bulk density for $8.0 \%$ glass content is $2.32 \mathrm{~g} / \mathrm{cm}^{3}$.

\subsection{Optimum Glass Content}

From Figures 3 to 6 , it is evident that all values of Marshall Stability for different glass contents satisfy the Asphalt Institute and the Nigerian code (i.e. $5.3 \mathrm{kN}$ and $3.5 \mathrm{kN}$, respectively). However, the maximum stability (i.e. $17.8 \mathrm{kN}$ ) which is one of the most important criteria was obtained at $8 \%$ glass cullet content. Because of this stability value the $\%$ air void at $8 \%$ glass cullet is also the optimum compared to other values. The corresponding air voids value is $3.9 \%$ at the same glass content, which is very close to the median air voids in the specifications. It was also noticed in Figure 6, that all the values of bulk density at different glass cullet content are close to each other, hence within the Asphalt Institute and the Nigerian code requirements. Table 7 illustrates a comparison of the mechanical properties of glasphalt containing 8.0\% glass cullet with the local specifications (Federal Ministry of Works, Nigeria, [19]) and the international specifications (The Asphalt Institute, [20]). 
As indicated in Table 7, the glasphalt mix with optimum glass content of $8.0 \%$ by weight of aggregates satisfy all the requirements of The Asphalt Institute and Federal Ministry of Work, Nigeria specifications for HMA production.

\section{CONCLUSIONS}

Series of laboratory testing were performed in this study to investigate the feasibility of using waste glass cullet as partial replacement of fine aggregate in HMA production. The following conclusions can be drawn from the study.

i. The fine sized glass cullet from waste glass bottle exhibit behaviour similar to natural aggregate (Sand or crushed rock), and its gradation was similar to normal fine aggregates used in asphalt mixtures.

ii. Cullet from waste glass bottle with a maximum size of $4.75 \mathrm{~mm}$ can be used to partially replace fine aggregate.

iii. The results of Marshall Stability, flow, bulk density and air voids tests of glasphalt were found to be consistent with specification range at different percentages $(5.0-10.0)$ of glass contents, with better results $(17.8 \mathrm{kN}, 3.4 \mathrm{~mm}$, $2.32 \mathrm{~g} / \mathrm{cm}^{2}$, and $3.9 \%$ ) achieved at $8.0 \%$ glass content.

\section{REFERENCES}

[1] V.W.Y. Tam and C. M. Tam "A review on the viable technology for construction waste recycling," Journal of Resources, Conservation and Recycling, vol. 47, issue3, p. 209-221, 2006

[2] A. Arulrajah, J. Piratheesan, T. Aathheesan and M. W. Bo "Geotechnical properties of recycled crushed bricks in pavement applications," Journal of Mater. Civil Engineering/(ASCE) MT.1943-5533, 2011

[3] A. A. Murana and L. Sani "Partial Replacement of Cement with Bagasse Ash in Hot Mix Asphalt," Nigerian Journal of Technology, vol. 34, no. 4, p. 699 - 704, 2015

[4] H. S. Otuoze and A. A. Shuaibu "An Experimental Study on the Use of Polypropylene Waste in Bituminous Mix," Nigerian Journal of Technology, vol. 36, no. 3, p. $677-685,2017$

[5] I. E. Tobore "Solid Waste Management in Nigeria, "A paper presentation on Waste Management, Lagos, p. 7, 2012

[6] B. J. Leite and D. D. Young "Use of Waste Glass as Aggregate for Pavement Material," Department of
Engineering and Construction, City of Toledo, Ohio, 1971

[7] A. Neilson "Local Solutions Using Recycled Products in Public Works Sustainability," Victoria, Melbourne, Australia, 2009

[8] Japan Asphalt Pavement Association, JAPA “Waste Glass Bottle for Pavements, " Clean Japan Centre, Tokyo, p. D32-38, 1996

[9] N. Su and J. Chen "Engineering properties of asphalt concrete made with recycled glass," Journal of Resources, Conservation and Recycling, Vol. 35, p. 259-274, 2002

[10] P. Kandahl "Waste materials in hot mix asphalt," National Center for Asphalt Technology, NCAT, Report 92-06, 1992

[11] K. Viswanathan "Characterization of waste recycled glass as a highway material, "Unpublished M. Sc. Thesis, Texas Tech University, United States, 1996

[12] S. Wu, W. Yang and Y. Xue "Preparation and Properties of Glass-asphalt Concrete," Key Laboratory for Silicate Materials Science and Engineering Ministry of Education, Wuhan University of Technology, Wuhan 430070, P.R China, 2003

[13] I. Finkle, K. Ksaibati and T. Robinson "Recycled glass utilization in highway construction," Transportation Research Board, 86th Annual Meeting (No. 07-0929), 2007

[14] H. Jony, M. Al-Rubaie and I. Jahad "The effect of using glass powder filler on hot asphalt concrete mixtures properties," Journal of Engineering \& Technology, Vol. 29, No.1, p. 44-57, 2011

[15] TRB "Manual for Design of Hot Mix Asphalt with Commentary," NCHRP report 673, Transportation Research Board, Washington, D.C., USA, 2011

[16] ASTM D5581-96 “Test Method for Resistance to Plastic Flow of Bituminous Mixtures Using Marshall Apparatus," Annual Book, Philadelphia, US, 2000

[17] S. Jendia "Highway Engineering: Structural Design," Palestine Dar almanara Library, First Edition, Gaza, Palestine, p.63-68, 2000

[18] C. O’Flaherty “Highways (The Location, Design, Construction and Maintenance of Road Pavements,". Butterworth-Heinemann, Fourth edition, 2002

[19] Nigerian general specification - Roads and bridges. Federal Ministry of Works, Lagos, 1997

[20] Asphalt Institute "Mix Design Methods for Asphalt Concrete and Other Hot-Mix Types," Manual Series No. 2 (MS-2), Sixth Edition, Asphalt Institute, Lexington, Kentucky, 1997. 